\title{
BİLSEM Tarih Öğretmenlerinin BİLSEM Çalışma Koşulları Hakkındaki Görüşleri
}

\author{
BİLSEM History Teachers' Opinions on BILSEM Working Conditions
}

\section{Osman AKHAN ${ }^{1}$, Sedat ALTAŞ²}

\begin{abstract}
Öz
$\mathrm{Bu}$ araştırmanın amacı, BİLSEM'lerde çalışan tarih öğretmenlerinin çalışma koşullarına yönelik görüşlerini ortaya koymaktır. Nitel araştırma yönteminin kullanıldığı bu araştırmada, betimsel model benimsenmiştir. Bu doğrultuda çalışma, 2020-2021 eğitim öğretim döneminde, Türkiye'nin çeşitli illerindeki BILLSEM'lerde görev yapan 27 tarih öğretmeni ile yürütülmüştür. Araştırmanın verileri araştırmacılar tarafından hazırlanan yarı yapılandırılmış görüşme formu yardımı ile toplanmışır. Araştırmadan elde edilen veriler betimsel analiz ile çözümlenmiştir. Araştırmanın sonuçlarına bakıldığında, çalışma grubundaki tarih öğretmenlerinin BíLSEM'lerde en önemli sorun olarak, idarecilerin BİLSEM'lere uygun atama biçimi ile atanmamalarından ve öğrencilerin okul ve BİLSEM eğitimini beraber sürdürmelerinden kaynaklandığını ifade ettikleri görülmüştür. Tarih dersi özelinde ise katılımcılar tarih dersinin önemsenmeyen bir ders olduğu görüşünü paylaşmış ve bu duruma idarecilerin, ailelerin ve öğrencilerin tarih alanına bir bilim olarak bakmamalarının sebep olduğunu belirtmişlerdir. Araştırmanın sonuçlarını genel olarak değerlendirmek gerekirse, çalışma grubundaki öğretmenlerin çalışma koşulları konusunda yaşanan eksikleri olmasına rağmen kurumda olmaktan mutlu oldukları ve BILSEM'de çalışmaya devam etme konusunda istekli oldukları ve beklentilerinin karşılanması yönünde atılacak adımların motivasyonlarına ve verimliliklerine katkı sağlayacağını söylemek mümkündür.
\end{abstract}

Anahtar Kelimeler

BİLSEM

Tarih

Öğretmen

Çalışma koşulları

\begin{abstract}
The purpose of this research is to reveal the views of history teachers working in BILLEMs about their working conditions. The descriptive model was adopted in this study, in which the qualitative research method was used. In this perspective, the present study was conducted with 27 history teachers working in BILSEMs in various cities in Turkey in the 2020-2021 academic year. The research data were collected with the help of semi-structured open-ended questions prepared by the researchers. The data obtained from the research were analyzed by descriptive analysis. When the results of the study were examined, it was seen that the most important problem of the history teachers in the sample was that the administrators were not assigned to BILSEMs with the appropriate appointment procedures and that the students attended their normal school and BILSEM education at the same time. As for the history lesson, the participants shared the view that history lesson is an underestimated lesson and stated that this is the reason why administrators, families and students do not consider history as a science. When the results of the research are evaluated in general, it is possible to say that the teachers in the sample are happy to be in the institution despite the deficiencies in their working conditions, are willing to continue working at BILSEM, and the steps to be taken to meet their expectations will contribute to their motivation and efficiency.
\end{abstract}

Keywords

BILSEM

History

Teacher

Working conditions

\begin{tabular}{lll}
\hline Başvuru Tarihi/Received & Kabul Tarihi/Accepted \\
23.04 .2021 & | Araştırma Makalesi / Research Article $\mid$
\end{tabular}

Akhan, O., \& Altaş, S. (2021). BILLSEM history teachers' opinions on BİLSEM working conditions. Manisa Celal Bayar University Journal of the Faculty of Education, 9(1), 133-147. https://doi.org/10.52826/mcbuefd.924337.

1 Sorumlu Yazar, Dr. Öğretim Görevlisi, Akdeniz Üniversitesi, Eğitim Fakültesi, Sosyal Bilgiler Eğitimi, Antalya, TÜRKIYE; osmanakhan@akdeniz.edu.tr, (iD https://orcid.org/0000-0001-6532-7985

2 Tarih Öğretmeni, Antalya Bilim Sanat Merkezi, Antalya, TÜRKIYE; (iD https://orcid.org/00000000-0002-5863-8707 


\section{GİRIŞ}

Sürekli bir değişim ve yenilenmenin yaşandığı dünya koşullarına adaptasyon sürecinde nitelikli insan yetiştirme çabası günümüzde çok önemli bir hal almıştır. Bu süreçte ise en büyük görev ve sorumluluk öğretmene düşmektedir. Ulusal ve evrensel kültürel mirasın aktarımında ve bireylerin sahip olduğu potansiyellerini yansıtmalarında aracı rolü olan ve onların gelişimine yönelik çaba sergileyen öğretmenlerin icra ettikleri meslek, geçmişte de günümüzde de diğer mesleklerden farklı ve özel bir yere oturtulmaktadır (Güven, 2010). Öğretmenler doğrudan sınıf içerisindeki öğrencilere sınırlı bir zaman dilimi içerisinde öğrenmelerine kılavuzluk etse de uzun vadede çağlara hitap etmekte ve bir nesli yönlendirmektedir (Karataş, 2020). Bu bakımdan öğretmenlerin iyi yetişmiş olmaları ve zaman içerisinde kendilerini yenileme adına çalışmalarda bulunmaları gereklidir. Ülkemizin geleceği açısından önemli bir yer teşkil eden Bilim ve Sanat Merkezleri (BILSEM)'nde görev alan öğretmenlerin ise bu kurumlarda eğitim alan öğrencilerin gelişim süreçlerine uygun çözümler sunabilmesi için daha çok çaba harcamaları gerektiği açıktır.

Ülkemizde, ilk kez üstün yetenekliliğin tanımı 2916 Sayılı Kanununun 20. maddesine dayanılarak çıkartılan Özel Eğitim Okulları Yönetmeliği'nde yapılmış; yönetmeliğin 6. Maddesinde üstün zekâlılar: "zekâ bölümü çeşitli ölçeklerde sürekli olarak 130 ve daha yukarı olanlar" şeklinde tanımlanmıştır (MEB, 1991). Özel Eğitim ve Rehberlik ve Danışma Hizmetleri Genel Müdürlüğü 1992 yılında bu çocukların eğitimlerini sağlamak amacıyla kurulmuştur. Bu dönemde farklı ülkelerde uygulanan modeller incelenerek; 1993 Bilim ve Sanat Merkezi (BİLSEM) adıyla beş ilde (İstanbul, Ankara, İzmir, Denizli ve Bayburt) pilot uygulama hayata geçirilmiştir (Dönmez, 2019). Günümüzde ülkemizde özel yetenekliler eğitimiyle ilgili olarak devlet eliyle sağlanan eğitim; BíLSEM'lerde devam etmektedir. Ağustos 2019 itibari ile bu merkezlerin sayısı 160'ı bulmuştur ve bu BİLSEM'lerden yaklaşık Altmış üç bin çocuk yararlanmaktadır (MEB, 2019). Öğrencilere Bilsem'lerde kabiliyetleri doğrultusunda eğitim verilmektedir. Bu doğrultuda her merkezin bulunduğu koşullara göre; uyguladığı etkinlikler, yapısı ve çalışma koşulları birbirinden farklı olabilmektedir.

BILSEM'lerde verilen tarih dersinde özel yetenekli öğrencilerin; araştırma becerisine sahip, analiz, sentez ve değerlendirme yapabilen, bilimsel okuryazarlık becerisi gelişmiş, yeni teknolojiler ve projeler üretebilen, bilimsel süreç becerilerini kullanabilen, eleştirel düşünebilen, yaratıcı, yansıtıcı ve araştırıcı, tarihsel empati kurabilen bireyler olarak yetişmeleri beklenmektedir (MEB, 2019). Bu beklenti doğrultusunda; BİLSEM'lerde eğitim alan özel yetenekli öğrencilere yönelik öğretim programı oluşturulurken; öğrencilerin hazırbulunuşluk düzeyleri, sahip oldukları yetenekler, beklentileri ve içinden geldikleri sosyo-kültürel özellikler dikkate alınarak farklılaştırılmış ve zenginleştirilmiş öğretimin ön plana çıarıldığı bireysel eğitim planlaması (BEP) yapılmalıdır (Mertol, 2014). Bu itibarla bu derste, özel yetenekli çocuklara verilen eğitimin çok iyi bir şekilde yapılandırılması ve sunulması büyük önem arz etmektedir (Çal, 2018). BİLSEM'lerde BEP temelli tarih programının hazırlanması ve uygulanmasının sorumluluğu diğer branşlarda olduğu gibi tarih öğretmenlerine bırakılmıştır.

Tarih dersi öğretim yöntem ve tekniklerinin kullanımı açısından birtakım zorluklar barındırdığı gibi eğitim sistemi içinde de diğer derslerden farklı sorunlara sahiptir. Türkiye'de tarih öğretiminin durumunu ele alan Safran (2009), tarih öğretimini, eğitim sistemimizdeki en sorunlu alanlardan biri olarak tarif eder. Bu bakımdan tarih öğretmenlerinin işi oldukça zordur. Bu duruma öğretmenin çalışma koşulları ve bulunduğu ortama yönelik olumsuz tutumu da eklendiğinde sonuç hiç de iç açıcı olmayabilmektedir. Nitekim yapılan araştırmalar; okulda mutlu olan çalıştığı okul ile ilgili olumlu tutumlara sahip öğretmenlerin mesleklerinde performans ve verim artışı yaşadığını göstermektedir (Yörük, Çankaya, Büyükakın ve Kızılkaya, 2013; Terzi, 2017; Agaoğlu, 2011).

Alan yazına bakıldığında BİLSEM öğretmenlerinin çalışma koşulları ve mesleki algılarına ilişkin görüşlerinin ele alınıp incelendiği çalışmalara bakıldığında, örneğin Semerci ve Kaya (2007), BİLSEM'lerde görev yapan öğretmenlerin BİLSEM'e yönelik görüşlerini araştırdıkları çalışmalarında; öğretmenlerin BİLSEM'e yönelik olumsuz görüşlerinin bulunmadığı, çalışırken zorlanmadıkları, ancak diğer BILLSEM'ler ve üniversitelerle iletişim kurmak istedikleri sonucuna ulaşmışlardır. Bozan ve Savi-Çakar (2020), Bilim ve Sanat Merkezlerinde görev yapan 
öğretmenlerin karşılaştıkları sorunlar ve bu sorunlara ilişkin çözüm önerilerinin ortaya koyulmasının amaçlandığı çalışmalarında, öğretmenlerin Bilim ve Sanat Merkezlerinde ders saatlerinin hem öğretmenler hem de öğrenciler için uygun olmadığını yoğun olarak ifade ettikleri; eğitsel anlamda, çalıştıkları merkezde araç-gereç ve materyal eksikliği yaşadıkları, merkezlerin fiziki donanım olarak yetersiz olduğu, Bilim ve Sanat Merkezlerinin çerçeve programlarında yer alan etkinliklerin içerik bakımından sorunlar içerdiğii, yöneticilerle iletişim sıkıntısı yaşadıkları, yöneticilerin kurumun başarısı nedeniyle sonuç odaklı düşündükleri ve öğretmenlere sunulan olanaklar açısından adaletli olmadıkları görüşünde oldukları sonucuna ulaşmışlardır. Akhan ve Altaş (2020) ise, BİLSEM'lerde çalışan sosyal bilgiler öğretmenlerinin çalışma koşullarına yönelik görüşlerinin araştırıldığı çalışmalarında, öğretmenlerin, BİLSEM'lerde en büyük sorun olarak öğrencilerin kuruma karşı aidiyet duygusu yaşamaması görüşünde oldukları; bu durumun temel sebebinin ise, BİLSEM'lerin tam zamanlı bir eğitim vermemesi olduğunu düşündükleri sonucuna ulaşmışlardır. Ayrıca çalışma sonucuna göre; katılımcıların çoğu, BİLSEM'lerin işleyişiyle ilgili olarak; öğrenci seçim şeklinin değiştirilmesi, fiziksel imkân ve teknolojik altyapının iyileştirilmesi, üniversitelerle bağlantının daha çok artması gerektiği görüşünü paylaşmışlardır. Sosyal Bilgiler dersi özelinde ise katılımcıların çoğu Sosyal Bilgiler dersinin önemsenmeyen bir ders olduğu görüşünü paylaşmış ve bu duruma idarecilerin, ailelerin ve çocukların Sosyal Bilgiler alanına bir bilim olarak bakmamalarının sebep olduğunu belirtmişlerdir. İdarecilerin, velilerin ve öğrencilerin sayısal derslere verdikleri önemi bu derse de vermeleri gerektiğini ifade etmişlerdir. Bu çalışmalar dışında alan yazında BİLSEM'de görev yapan tarih öğretmenlerine yönelik herhangi bir araştırmaya rastlanmamıştır.

BİLSEM'lerde tarih programının hazırlayıcısı ve uygulayıcısı olan tarih öğretmenleri birçok sorunla karşı karşıya kalabilmektedir. Bu öğretmenlerin BİLSEM'lere yönelik görüşlerinin neler olduğunun bilinmesi, BİLSEM'lerin örgütsel yapısı, işleyiş̧i ve bu işleyiş sırasında karşılaşılan sorunlar konusunda açıklayıcı olacaktır. Bu bakımdan araştırmanın amacı, Türkiye'deki BİLSEM'lerde görev yapan tarih öğretmenlerinin çalışma koşullarına yönelik görüşlerini ortaya koymaktır.

\section{YÖNTEM}

\section{Araştırmanın Modeli}

Nitel araştırma yöntemi kullanılan bu araştırmada, betimsel model benimsenmiştir. "Betimsel çalışmalar araştırmaya konu olan olay, birey ya da nesneyi, kendi koşulları içinde ve olduğu gibi tanımlanmaya çalışır. Onları herhangi bir şekilde değiştirme, etkileme çabası göstermez" (Karasar, 2012). Bu doğrultuda araştırmada, BİLSEM'lerde çalışan tarih öğretmenlerinin çalışma koşullarına yönelik görüşlerini ortaya koymak amaçlanmıştır.

\section{Çalışma Grubu}

Bu çalışma, 2020-2021 eğitim-öğretim döneminde, amaçlı örnekleme yöntemlerinden kolay ulaşılabilir örneklemeye göre belirlenmiş, Türkiye'nin çeşitli illerindeki Bilim ve Sanat Merkezlerinde görev yapan, 27 tarih öğretmeni ile gerçekleştirilmiştir. Çalışma grubuna ait bazı özellikler Tablo 1'de verilmiştir.

Tablo 1. Çalışma Grubuna Ait Bazı Özellikler

\begin{tabular}{|c|c|c|c|}
\hline Özellikler & & $\mathrm{N}$ & $\%$ \\
\hline \multirow{2}{*}{ Cinsiyet } & Kadın & 12 & 44,4 \\
\hline & Erkek & 15 & 55,5 \\
\hline \multirow{3}{*}{ Öğrenim Durumu } & Lisans & 2 & 7.4 \\
\hline & Yüksek Lisans & 24 & 88,8 \\
\hline & Doktora & 1 & 3,7 \\
\hline \multirow{4}{*}{ Kidem Y1lı } & $1-7$ & - & - \\
\hline & $8-15$ & 8 & 29,6 \\
\hline & $16-23$ & 12 & 44,4 \\
\hline & $24-31$ & 7 & 25,9 \\
\hline \multirow{3}{*}{ BİLSEM Çalışma Süresi } & $1-3$ & 10 & 37 \\
\hline & $4-7$ & 16 & 59,2 \\
\hline & $8-11$ & 1 & 3,7 \\
\hline
\end{tabular}


Tablo 1 incelendiğinde çalışma grubundaki erkek öğretmenlerin $(n=15)$ kadın öğretmenlerden $(n=12)$ daha fazla sayıda olduğu görülmektedir. Öğrenim durumuna göre öğretmenlerin en çok yüksek lisans (n=24), daha sonra lisans ( $n=2)$, en az ise doktora $(n=1)$ mezunu oldukları tespit edilmiştir. Çalışma grubunu oluşturan öğretmenlerin kıdem yıllarına bakıldığında ise, çoğunluğun 16-23 (n=12) yıl aralığında olduğu; grupta 1-7 kıdem yılını kapsayan hiçbir öğretmenin olmadığı belirlenmiştir. Öğretmenlerin BİLSEM'deki çalışma süreleri bakımından ise çoğunluğunun 4-7 yıl (n=16) aralığında BİLSEM'de çalışmakta oldukları söylenilebilir.

\section{Veri Toplama Aracı ve Verilerin Toplanması}

Araştırmanın verileri araştırmacılar tarafından hazırlanan yarı yapılandırılmış görüşme formu yardımı ile toplanmıştır. Hazırlanan açık uçlu sorular "Google Form" aracılığıyla soru formuna aktarılmış ve ardından tarih öğretmenlerine telefonun WhatsApp hizmeti ile ulaşılarak soruları yanıtlamaları istenmiştir. Sorularda genel olarak, “Tarih öğretmenlerinin; BİLSEM'in örgütsel yapısına, işleyişine, yöneticilere ve öğrencilere karşı tutumlarında olumlu veya olumsuz görüşe neden olan durumlarına ve BİLSEM'den tarih alanıyla ilgili beklentilerinin karşılanıp karşılanmadığına yönelik" sorular sorulmuştur.

\section{Verilerin Analizi}

Araştırmadan elde edilen veriler betimsel analizi tekniği ile çözümlenmiştir. Betimsel analizde elde edilen veriler önceden belirlenen temalara göre özetlenerek yorumlanmaktadır. Ayrıca betimsel analizde veriler temalara göre düzenlenebileceği gibi, gözlem ve görüşme süreçlerinde kullanılan soru veya boyutlar dikkate alınarak da sunulabilir (Yıldırım ve Şimşek, 2013). Araştırmanın güvenirliğini artırması bakımından verilerin betimsel analizleri araştırmacıların dışında tarih alanında uzman iki öğretim üyesinin de yardımı ile birlikte gerçekleştirilmiştir. Araştırmanın güvenirliği için Miles ve Huberman (1994)'ın önerdiği R(Güvenirlik) = [Na (Görüş Birliği) / Na (Görüş Birliği) + Nd (Görüş Ayrılığı)] x 100 formülü kullanılmıştır. Yapılan hesaplamaya göre araştırmacılar arasındaki uyum \%86 olarak hesaplanmış ve araştırmanın analizi güvenilir kabul edilmiştir. Ayrıca bulgular öğretmen adaylarının görüşlerinden (Ö1: 1. öğretmen, Ö2: 2. öğretmen şeklinde) doğrudan alıntılarla desteklenmiştir.

\section{Araştırmanın Etik İzinleri}

Etik değerlendirmeyi yapan kurul adı: Akdeniz Üniversitesi Sosyal ve Beşeri Bilimler Bilimsel Araştırma ve Yayın Etiği Kurulu

Etik değerlendirme kararının tarihi: 18.09.2020

Evrak Tarih ve Sayısı: 23/09/2020-100607

\section{BULGULAR}

\section{BİLSEM Tarih Öğretmenlerinin BİLSEM'lerin Olumlu Taraflarına Yönelik Görüşlerine İlişkin Bulgular}

Tablo 2. Öğretmenlerin BILLSEM’lerin Olumlu Taraflarına Yönelik Görüşleri

\begin{tabular}{|c|c|c|}
\hline Tema & Görüşler & $\mathrm{f}$ \\
\hline \multirow{4}{*}{ Öğrencilerin Nitelikleri } & Zeki Olması & 3 \\
\hline & Yetenekli Olması & 2 \\
\hline & İlgili Olması & 1 \\
\hline & Özgür Düşünceye Sahip Olması & 1 \\
\hline \multirow{5}{*}{ Etkili Program } & Esnek Etkinlik Planları & 3 \\
\hline & Proje Tabanlı Eğitim & 2 \\
\hline & Üretkenlik & 1 \\
\hline & Çağdaş Değerlendirme Yöntemleri & 1 \\
\hline & Özgün Olması & 1 \\
\hline \multirow{4}{*}{ Çalışma Ortamı } & Rahat Çalışma Ortamı & 5 \\
\hline & Proje Yapma Kolaylığı & 2 \\
\hline & Düşünme Becerilerini Arttırabilme Ortamı & 2 \\
\hline & Değerli Olması & 1 \\
\hline
\end{tabular}




\begin{tabular}{ll} 
Etkinlik Olanakları & 1 \\
\hline Dinamiklik & 1 \\
\hline Akademik Çalı̧ma Ortamı & 1 \\
\hline Verimlilik & 1 \\
\hline Gönüllülük İlkesi & 1
\end{tabular}

Tablo 2 incelendiğinde BİLSEM tarih öğretmenlerinin BİLSEM'lerin olumlu taraflarına yönelik görüşleri değerlendirildiği zaman öğretmenlerin görüsslerinin "öğrenci, program, kurum" temaları altında toplandığ1 görülmektedir. BİLSEM tarih öğretmenlerinin görüşlerine bakıldığında en fazla olumlu görüşün çalışma ortamı teması altında "rahat çalışma ortamı" olarak ifade edildiği söylenebilir. Yine aynı tema altında öğretmenlerin görüşlerinin "proje yapma kolaylığı", "düşünme becerilerini arttırabilme ortamı" başlığı altında toplandığı ifade edilebilir. Etkili program teması altında öğretmenlerin görüşlerinin "esnek etnik planları", "proje tabanlı eğitim" başlıkları altında sıklıkla ifade edildiğini söylemek mümkündür. Öğrencilerin nitelikleri teması altında öğretmenlerin görüşlerinin "zeki olması", "yetenekli olması" başlıkları altında toplandığı görülebilir. Bulgular genel olarak değerlendirildiğinde ise, öğretmenlerin BİLSEM’lerin olumlu taraflarını yönelik görüşlerini üretkenliği ve verimliliği arttırıcı rahat çalışma ortamı sunması ve öğrencilerin bilgi düzeylerinin yüksek seviyede olması şeklinde ifade etmek mümkündür. Öğretmenlerin görüşlerinden bazıları şu şekildedir:

"Öğretmeni, öğrenciyi kalıba sokmadan rahat düşünme ve çalışma ortamı oluşturması" (KÖ, 2).

"Öğrencilerin yetenekli ve ilgili olması. Şartlara göre etkinlik düzenlenebiliyor olması." (EÖ,6).

"Proje tabanli eğitim vermesi" (EÖ, 13)

"Özel öğrencilerle ilgili ve yetenekli olduklar alanlarında derinlemesine çalışmak akademik çalı̧ma ortamın oluşturmak"

(KÖ,15).

"Öğrencilerin yeteneklerini keşfetmesinde onlara rehberlik etmesi ve onlara faydalı ve mutlu bir ortam sağlaması." (EÖ, 18).

\section{BİLSEM Tarih Öğretmenlerinin BİLSEM'lerin Sorunlarına Yönelik Görüşlerine İlişkin Bulgular}

Tablo 3. Öğretmenlerin BİLSEM’lerin Sorunlarına Yönelik Görüşleri

\begin{tabular}{|c|c|c|}
\hline Tema & Sorunlar & $\mathrm{f}$ \\
\hline \multirow{4}{*}{ Öğrenci ile İlgili } & Öğrencilerin Ders Yükünün Fazla Olması & 4 \\
\hline & Öğrencinin BİLSEM'i Değersizleştirmesi & 2 \\
\hline & Sorumluluk Sahibi Olmaması & 1 \\
\hline & Mezun Öğrencilere Yeterli Olanaklar Sağlanmaması & 1 \\
\hline \multirow{3}{*}{ Program ile İlgili } & Örgün Eğitime Entegre olmaması & 3 \\
\hline & İşlevsel olmaması & 2 \\
\hline & Geleneksel Değerlendirme Yöntemlerinin Olmaması & 1 \\
\hline \multirow{11}{*}{ Kurum ile İlgili } & Kurumsallığın Zayıf Olması & 4 \\
\hline & Fiziki Ortam Yetersizliği & 4 \\
\hline & Maddi Olanakların Yetersizliği & 4 \\
\hline & Çalışma Saatleri & 4 \\
\hline & BİLSEM'lerin MEM Tarafından Değersizleştirilmesi & 3 \\
\hline & BİLSEM'lerin Entegre Olamaması & 3 \\
\hline & Hizmet İ̧̇i Eğitimin Yetersizliği & 3 \\
\hline & Tanılama Yöntemi Yetersizliği & 2 \\
\hline & Prosedürlerin Fazlalığı & 1 \\
\hline & Öğrenci Sayısının Fazlalığı & 1 \\
\hline & Popülist Yaklaşımlar & 1 \\
\hline
\end{tabular}

Tablo 3 incelendiğinde öğretmenlerin BİLSEM'lerin sorunlarına yönelik görüşleri değerlendirildiği zaman öğretmenlerin görüşlerinin BíLSEM’lerin olumlu taraflarına yönelik görüşleri başlığı altında olduğu gibi; “öğrenci, program, kurum" ile ilgili temalar altında toplandığ görülmektedir. BİLSEM tarih öğretmenlerinin BİLSEM'lerin sorunlarına yönelik görüşlerine bakıldığında en fazla görüşün kurum ile ilgili teması altında toplandığını söylemek mümkündür. Kurum ile ilgili teması altında tarih öğretmenlerinin görüşlerinin "kurumsallığın zayıf olması", "fiziki ortam yetersizliğii", "maddi olanakların yetersizliği" ve "çalışma saatleri" başlıkları etrafında sıklıkla toplandığı ifade edilebilir. Program ile ilgili teması altında öğretmenlerin görüşlerinin en fazla "örgün eğitime entegre olmaması" başlı̆̆ı altında söylendiği görülmektedir. Öğrenci ile ilgili teması altında öğretmenlerin görüşlerinin 
“öğrencilerin ders yükünün fazla olması”, “öğrencilerin BíLSEM'i değersizleştirmesi” başlıkları altında toplandığını söylemek mümkündür. Bulgular genel olarak değerlendirildiğinde ise, BİLSEM'lerin sorunlarının kalıplaşmış idare yönetiminin olmaması, çalışma alanlarının yetersiz olması, öğretmenlerin çalışma saatlerinin örgün eğitim çalışma saatlerinden sonraya kalması, öğrencilerin örgün eğitim ile BİLSEM arasında ders yükümlülügünün fala olmasından dolayı verimliliğinin azalması şeklinde yorumlanabilir. Öğretmenlerin görüşlerinden bazıları şu şekildedir:

"Yerel yöneticilerin elinde değersizleşmesi" (EÖ, 1).

"Öğrencilerin okuldan sonra Bilsem'e geliyor olması. Öğrenci sayılarının fazla olması." (Ë̈, 6).

"Yapısal sorunlar. Örgün eğitime entegrasyon. Ölçme ve değerlendirmenin olmaması" (EÖ, 13).

"Öğrencilerin çok yoğun olması sınav kaygısı ve proje öğrencilerinin çalışmalarını vakit açısından etkilemesi” (KÖ, 15).

"Bağhı olduğumuz kurumların (Milli Eğitim Müdürlükleri) bizim çalışma koşullarımızı bilmemesinden kaynakl iş yapamama sorunu." (Ë̈, 24).

"Bizi bilgilendirecek kişilerin olmaması. Hizmet içi kurslarının yetersiz olması." (KÖ, 7).

\section{BİLSEM Tarih Öğretmenlerinin BİLSEM’lerin İşleyişi ile İlgili Değişmesini İstedikleri Hususlara Yönelik Görüşlerine İlişkin Bulgular}

Tablo 4. Öğretmenlerin BİLSEM'lerin İşleyişi ile İlgili Değişmesini İstedikleri Hususlar

\begin{tabular}{|c|c|c|}
\hline Tema & Değişmesini İstedikleri Hususlar & $\mathrm{f}$ \\
\hline \multirow{4}{*}{ Öğrenci ile İlgili } & Öğrencilerin Kurumda Kalma Süreleri & 3 \\
\hline & Öğrenci Belirleme Usulünün Değişmesi & 2 \\
\hline & Öğrencilerin Eğitiminin BİLSEM ile Sınırlı Olması & 2 \\
\hline & Öğrencilerin Bilgi Düzeylerinin Arttırılması & 1 \\
\hline \multirow{2}{*}{ Program ile İlgili } & Uygun Bir Ölçme ve Değerlendirme Yaklaşımı & 1 \\
\hline & Öğrenci Merkezli Dizayn Edilmesi & 1 \\
\hline \multirow{9}{*}{ Kurum ile İlgili } & Yöneticilerin Atanma Usulü & 5 \\
\hline & Çalışma Saatleri & 5 \\
\hline & Fiziksel Olanakların Arttırılması & 3 \\
\hline & Hizmet İçi Eğitimin Arttırılması & 3 \\
\hline & Okul ve Kurumun Entegre Olmasi & 2 \\
\hline & Okul Statüsüne Kavuşması & 2 \\
\hline & BİLSEM'lerin MEM Yerine Doğrudan MEB'e Bağlanmas1 & 2 \\
\hline & BİLSEM'lerin Öneminin Artması & 1 \\
\hline & Öğretmenlerinin Lider Özelliği Taşıyan Kişilerden Seçilmesi & 1 \\
\hline
\end{tabular}

Tablo 4 incelendiğinde öğretmenlerin BİLSEM'lerin işleyişi ile ilgili değişmesini istedikleri hususlara yönelik görüşleri değerlendirildiği zaman tarih öğretmenlerinin görüşlerinin yine diğer başlıklar altında olduğu gibi; “öğrenci, program ve kurum” ilgili temalar altında toplandığ1 görülmektedir. Öğretmenlerin görüşlerine bakıldığında en fazla görüşün kurum teması altında "yöneticilerin atanma usulü" ve "çalışma saatleri" altında sıklıkla söylendiği ifade edilebilir. Program teması etrafında en fazla görüşün "uygun bir ölçme ve değerlendirme yaklaşımı", öğrenci teması etrafında en fazla görüşün “öğrencilerin kurumda kalma süreleri” görüşü etrafında toplandığı görülmektedir. Bulgular genel olarak değerlendiğinde ise, tarih öğretmenlerinin BíLSEM'lerin işleyişi hakkında öğrencilerin mevcut örgün eğitimi gördükten sonra geri kalan saatlerini BíLSEM' e ayırmalarının BİLSEM'de görevli öğretmenlerin günün geç saatlerinde çalışma imkânı bulmasından kaynaklı ortaya çıan sorunların giderilmesi ve fiziksel olanakların iyileştirilmesine yönelik değişimlerim olması yönünde görüş bildirdiklerini söylemek mümkündür. Öğretmenlerin görüşlerinden bazıları şu şekildedir:

\footnotetext{
"Öğrencilerin devam ettiği okulla programı entegre olması gerektiğine inanıyorum" $(E O ̈, 4)$.

"Derslerin daha makul bir saate alınmasin isterim en azından 6'dan sonra ders olmamasinı" $(K O ̈, 14)$.

"İdareci ataması diğger okullardan farklı olmalı mevcut düzenleme değişmeli." (EÖ, 18).

"Müdürlerin merkezden atanması gerekiyor. İlçe Milli Ĕ̆itim Müdürlüğ̈̈ değil direkt özel yeteneklilerin geliştirilmesi daire başkanlı̆̆ına bă̆lanmalıyız." (EÖ, 23).

"Daha çok tanınırlı̆̆ının olması ve öğrencinin öğretim kurumu olarak birinci önceliğinin BILLSEM olmasın isterim." (EÖ, 27).

“Hizmet içi eğitimlerle, kurslarla eksikliklerimizin giderilmesini ve daha fazla bilogi almayı isterim." (EÖ, 1).
} 
BİLSEM Tarih Öğretmenlerinin Kurumda Kendilerini Nasıl Hissettikleri Hakkındaki Görüşlerine İlişkin Bulgular

Tablo 5. Öğretmenlerin Kurumda Kendilerini Nasıl Hissettikleri Hakkındaki Görüşleri

\begin{tabular}{lll}
\hline Tema & Hisler & $\mathrm{f}$ \\
\hline \multirow{4}{*}{ Olumlu } & İyi & 8 \\
\cline { 2 - 3 } & Mutlu & 7 \\
\cline { 2 - 3 } & Özgür & 5 \\
\cline { 2 - 3 } & Üretken & 2 \\
\cline { 2 - 3 } & Harika & 1 \\
\cline { 2 - 3 } Olumsuz & Aitlik & 1 \\
\hline & Yalnuz & 5 \\
\cline { 2 - 3 } & Belirsizlik & 3 \\
\cline { 2 - 3 } & Huzursuz & 2 \\
\hline
\end{tabular}

Tablo 5'e bakıldığında öğretmenlerin kurumda kendilerini nasıl hissettikleri hakkındaki görüşleri incelendiği zaman tarih öğretmenlerinin görüşlerinin "olumlu" ve "olumsuz" temaları altında toplandığı görülmektedir. Olumlu teması içerisinde öğretmenlerin görüşlerinin "iyi" ve "mutlu” görüşleri etrafında sıklıkla toplandığı ifade edilebilir. Olumsuz teması içerisinde öğretmenlerin görüşlerinin ise "yalnız" ifadesi etrafında yoğunlaştı̆̆ını söylemek mümkündür. Bulgular genel olarak değerlendirildiğinde ise, BİLSEM tarih öğretmenlerinin kurum içerisinde kendilerini öğrencilerin proje temelinde üretkenliğini ve yaratıcllğını arttırma imkânı oluşturabildikleri için özgür ve mutlu, kurum içerisinde idare ile öğretmen arasında koordine eksikliğinden dolayı belirsiz ve yalnız hissettiklerini ifade etmek mümkündür. Öğretmenlerin görüşlerinden bazıları şu şekildedir:

"Baskı altında olmadan öğrencinin gelişimine uygun etkinlik yapmak güzel" (EÖ, 7).

"Memnunum. İdare çok iyi. Beni rahat bırakıyor." (KÖ, 12).

"Mutluyum. Rahatım. Ama daha üretken olabilme isteğindeyim." (EÖ, 24).

"Çoğunlukla mutluyum ve çalışmak istediğim ortamdayım." (EÖ, 25).

"Mutlu ama geleceğge dair belirsiz." (EÖ, 26).

BİLSEM Tarih Öğretmenlerinin, BİLSEM'deki İdarecilerinden Tarih Dersine Karşı Tutum Durumlarına Yönelik Görüşlerine İlişkin Bulgular

Tablo 6. Öğretmenlerin, BİLSEM'deki İdarecilerinden Tarih Dersine Karşı Tutum Durumları

\begin{tabular}{lll}
\hline Tema & Tutumlar & $\mathrm{f}$ \\
\hline \multirow{5}{*}{ Olumlu } & İyi & 9 \\
\cline { 2 - 3 } & Değer Verme & 4 \\
\cline { 2 - 3 } & Destekleme & 3 \\
\cline { 2 - 3 } & Eşit & 2 \\
\cline { 2 - 3 } & Güzel & 1 \\
\cline { 2 - 3 } & Sorunsuz & 1 \\
\hline \multirow{3}{*}{ Olumsuz } & Önem Vermeme & 4 \\
\cline { 2 - 3 } & Vizyon Eksikliği & 2 \\
\cline { 2 - 3 } & İsteklerin Karşlanmaması & 2 \\
\cline { 2 - 3 } & Desteklememe & 1 \\
\hline
\end{tabular}

Tablo 6 incelendiğinde öğretmenlerin BíLSEM'deki idarecilerinden tarih dersine karşı tutum durumlarına yönelik görüşleri değerlendirildiği zaman BILSEM tarih öğretmenlerinin "olumlu" ve "olumsuz" temaları etrafında görüş bildirdikleri ifade edilebilir. Öğretmen adaylarının görüşlerinin olumlu teması altında "iyi" ve "değer verme" görüşleri etrafında daha fazla toplandığı, olumsuz teması altında ise "önem vermeme" ve "vizyon eksikliği" görüşleri etrafında daha fazla toplandığı söylenebilir. Bulgular genel olarak değerlendirildiğinde öğretmenlerin BİLSEM'deki idarecilerinden tarih dersine karşı tutum durumlarının çoğunlukla tarih dersinin bilimsel ağırlığından ve gerekliliğinden dolayı olumlu yönde olduğunu, az sayıda öğretmenlerin ise idarecilerin sorumluluk bilincinin düşüklügünden kaynaklı olumsuz yönde olduğunu söylemek mümkündür. Öğretmenlerin görüşlerinden bazıları şu şekildedir: 
"Olmasa da olur anlayışı ve vizyon eksikliği" (EÖ, 1).

"Çok iyi milli manevi ve kültürel değerlerimizin bilsem öğrencilerinde öncelikle olması gerektiğini düşünüyorlar ve destekliyorlar" (KÖ, 15).

"Tarih dersiyle uzaya çıklmaz, sonuçta bu derse maddi manevi destek te gereksizdir. Düşüncesi" (KÖ, 21).

"Ürettiğimiz sürece sıkıntı yok ancak bilişim ya da matematiğge olan ilgi ve destek Tarihe yok. Çoğu zaman isteklerimiz karşılanmiyor." (EÖ, 23).

"Kültürel mirası önemseyen bir müdürümüz var. O yüzden sorun yok." (EÖ, 25).

\section{BİLSEM Tarih Öğretmenlerinin, İdarecilerinden Tarih Dersine Yönelik Beklentileri Hakkındaki Görüşlerine İlişkin Bulgular}

BİLSEM tarih öğretmenlerinin, idarecilerden tarih dersine yönelik beklentilerine ilişkin görüşlerine bakıldığında 16 tarih öğretmeninin derslerine ilişkin beklentilerinin olduğu, 11 öğretmenin ise idarecisinden derslerine ilişkin beklentilerinin olmadığını ifade ettikleri görülmüştür.

Tablo 7. Öğretmenlerin, İdarecilerinden Tarih Dersine Yönelik Beklentileri

\begin{tabular}{ll}
\hline Beklentiler & $\mathrm{f}$ \\
\hline Tarih Dersini Önemsemeleri & 6 \\
\hline Proje & 4 \\
\hline Fiziksel Yeterliliklerin Arttırlması (Derslik, Atölye vb.) & 4 \\
\hline Sosyal Bilimleri Önemsemeleri & 2 \\
\hline Maddi ve Manevi Destek & 2 \\
\hline Eşit & 1 \\
\hline Etkinliklere Katılım (Okul Dışı Öğrenme Ortamları, Atölyeler vb.) & 1 \\
\hline Öğretmenleri Önemsemeleri & 1 \\
\hline
\end{tabular}

Tablo 7 incelendiğinde öğretmenlerin, idarecilerden tarih dersine yönelik beklentilerine ilişkin görüşlerine bakıldığı zaman öğretmenlerin görüşlerinin "tarih dersini önemsemeleri" ve "proje" görüşleri etrafında sıklıkla toplandığı söylenebilir. Öğretmenlerin ifadelerinin "fiziksel yeterliliklerin arttırılması (derslik, atölye vb.)" ve "sosyal bilimleri önemsemeleri” görüşleri etrafında da şekillendiği görülmektedir. Bulgular genel olarak değerlendirildiğinde BİLSEM tarih öğretmenlerinin idarecilerinden tarih dersine gerekli ilgi ve alakayı göstermeleri, tarih atölyeleri ile tarih sınıfları için maddi-manevi destek sağlamaları ve öğrencilerin geçmiş ile bugün arasında muhakeme edebilmelerini sağlamak için tarihsel empatiyi geliştirecek projelere öncülük etmeleri yönünde beklentilerinin olduğunu söylemek mümkündür. Öğretmenlerin görüşlerinden bazıları şu şekildedir:

"Atölye ortamını zenginleştirmesi" (Ë̈, 4).

"Maddi destek sağlanabilir özellikle projeler için" (KÖ, 14).

"Tarih dersleriyle ilgili ortaokul ve lise proje hazırlama." (EÖ, 18).

"Öğrencileri bu derse negatif yönlendirme yerine üstün zekalı gençlerin tarih bilimiyle ilgili olup topluma bağhllhğının gelişmesi için bu dersin gerekliliğine kendilerinin inanması" (KÖ, 21).

"Tarih sımıfının alt yapısını güçlendirme. Malzeme alımı. Branşa karşı daha ciddi yaklaşım." (EÖ, 23).

\section{BİLSEM Tarih Öğretmenlerinin, Öğrencilerin Tarih Dersine Karşı ilgili Olup/Olmama Durumlarına Yönelik Görüşlerine İlişkin Bulgular}

BİLSEM tarih öğretmenlerinin, öğrencilerin tarih dersine karşı ilgili olup/olmama durumlarına yönelik görüşlerine ilişkin bulgulara bakıldığı zaman 15 öğretmenin ilgili, 8 öğretmenin kısmen, 2 öğretmenin ilgisiz şekilde öğrencilerinin durumlarını ifade ettiklerini söylemek mümkündür.

Tablo 8. Öğretmenlerin, Öğrencilerin Tarih Dersine Karşı İlgili Olup/Olmama Durumları

\begin{tabular}{lc}
\hline Görüşler & $\mathrm{f}$ \\
\hline Öğrencinin Aktifleştirilmesi & 3 \\
\hline Sayısal Derslerin Sınav Ağırlı̆̆ının Daha Fazla Olması & 1 \\
\hline Diğer Derslere Öğrencilerin İlgilerinin Kayması & 1 \\
\hline Ailelerin Sayısal Dersleri Daha Fazla Önemsemesi & 1 \\
\hline Okul Sınavları Zamanında İlgilerin Azalması & 1 \\
\hline Zenginleştirilmiş Bir Program & 1 \\
\hline Velinin Yaklaşımı & 1 \\
\hline Projelerin Yönlendirici Olması & 1 \\
\hline Kullanılan Öğretim Yöntemleri & 1 \\
\hline
\end{tabular}

|Manisa Celal Bayar University Journal of The Faculty of Education, 2021, Vol. 9, No. 1| 
Tablo 8 incelendiğinde öğretmenlerin, öğrencilerin tarih dersine karşı ilgili olup/olmama durumlarına ilişkin görüşlerine ait bulgulara bakıldığı zaman öğretmenlerin görüşlerinin "öğrencinin aktifleştirilmesi” görüşü etrafında toplandığını söylemek mümkündür. Ayrıca BİLSEM tarih öğretmenlerinin görüşlerinin söylenme sıklıklarının dağınık olarak ifade edildiği söylenebilir. Bulgular genel olarak değerlendirildiğinde ise öğretmenlerin çoğunun tarih dersinin aktif katılımı sağlaması ve tarihi olay örgüsünün neden-sonuç ilişkisi etrafında çözümlenmesinden dolayı tarih dersinin öğrencilerin ilgisini çektiğini, öğretmenlerden bir kısmının ise tarih dersinin toplumda sözel bir ders olması ve velilerin başarı algısının sayısal dersler etrafında değerlendirilmesini istemesinin öğrenci üzerinde baskı oluşturmasından dolayı tarih dersinin öğrencilerin ilgisini çekmediğini ifade etmek mümkündür. Öğretmenlerin görüşlerinden bazıları şu şekildedir:

\footnotetext{
"Zenginleştirilmiş bir program uyguladığımı zaman ilgi düzeyleri yükselmektedir." (EÖ, 1).

"Bazıları iç motivasyonlu diğerleri de öğretmene bağlı bir durum" (EÖ, 5).

"Evet, çok ilgili fakat sinavlar yaklaştıkça velinin yönlendirmesiyle ilgi azalıyor." (EÖ, 18).

"Yerine göre değişiyor. Siz sürekli aktif tutmak zorundasınız. Velinin yaklaşımı da etkiliyor." (EÖ, 23).

"Ben bunun benim performansıma bağh olduğunu düşünüyorum. Derste kullandı̆̆ım öğretim yöntemleri bu durumu etkiliyor." (EÖ, 27).
}

\section{BİLSEM Tarih Öğretmenlerinin, Öğrencilerinden Tarih Dersine Yönelik Beklentileri Hakkındaki Görüşlerine İlişkin Bulgular}

Tablo 9. Öğretmenlerin, Öğrencilerinden Tarih Dersine Yönelik Beklentileri

\begin{tabular}{ll}
\hline Görüşler & $\mathrm{f}$ \\
\hline Tarih Kültürü Edinmeleri & 10 \\
\hline Merak Duygusunu Geliştirmesi & 5 \\
\hline Bilimsel Araştırma Yöntemlerini Edinmeleri & 5 \\
\hline Milli Duyguları Geliştirmek & 4 \\
\hline Proje Geliştirme & 3 \\
\hline Tarih Dersine Karşı Olumlu Bakış Açısı Geliştirmesi & 2 \\
\hline Hayata Aktarabilme & 1 \\
\hline Etkinliklere Katılma & 1 \\
\hline Fiziksel Donanımların Arttırılması & 1 \\
\hline Geçmiş ile Gelecek Arasında Bağlantı Kurabilme & 1 \\
\hline Tarihsel Empati & 1 \\
\hline Muhakeme Yeteneğini Arttırması & 1 \\
\hline Ö̆ğretmene Değer Verilmesi & 1 \\
\hline Tablo incelendiğinde ŏğetmenlerinı ŏgrencilerinden tarih dersine yönelik beklentileri
\end{tabular}

Tablo 9 incelendiğinde öğretmenlerin, öğrencilerinden tarih dersine yönelik beklentileri hakkındaki görüşlerine ilişkin bulgulara bakıldığında öğretmenlerin görüşlerinin "tarih kültürü edinmeleri" görüşü etrafında daha fazla toplandığını ifade etmek mümkündür. Tarih öğretmenlerinin öğrencilerinden tarih dersine yönelik beklentilerinin "Merak duygusunu geliştirmesi" ve "bilimsel araştırma yöntemlerini edinmeleri" etrafında yoğunlukla şekillendiği söylenebilir. Ayrıca öğretmenlerin görüşlerinin çok yönlü olarak ifade edildiği görülmektedir. Bulgular genel olarak değerlendirildiğinde ise, tarih öğretmenlerinin öğrencilerinden tarihsel muhakeme yeteneği kazanıp, merak duygusunu en yüksekte tutarak milli bilincini ve duygusunu arttırması ve geçmiş ile gelecek arasında tarihsel açıdan kültürel birikime sahip olması yönünde beklentilerinin olduğunu söylemek mümkündür. Öğretmenlerin görüşlerinden bazıları şu şekildedir:

\footnotetext{
"Tarih kültürü edinmeleri, merak duygusunu canlandırarak bilimsel araştırma yöntemlerini edinmeleri" (EÖ, 4).

"Araştırma yapmaları ve bu çalışmalarını bilimsel yazıyla noktalayabilmeli" (KÖ, 10).

"Öncelikle tarih bilincinin olması ve bir milletin kültürel değerleri olmadan teknoloji bilimde ne kadar ilerlerse ilerlesin eksik kalacaklarm bilmelerini isterim" (KÖ, 15).

"Tarihi bilgileri yargılayacak kendilerinin doğrulamaya çalışması ve yeni bakış açılarıyla yeni bilgiler ortaya koyması" (KÖ, 21).

"Proje döneminde tarih dersini seçmeleri" (EÖ, 25).
} 
Tablo 10. Öğretmenlerin BİLSEM'lerde Olmasını İstediklerine Yönelik Görüşleri

\begin{tabular}{|c|c|}
\hline İstekler & $\mathrm{f}$ \\
\hline Okul Müzesinin Olması & 4 \\
\hline Tarih Sınıfının Olması & 3 \\
\hline Proje Odaklı Öğrencilerin Olması & 3 \\
\hline Öğrenci Devamlılığının Sağlanması & 3 \\
\hline Zaman Engelinin Kalkması & 3 \\
\hline Tarih Dersinin Önemsenmesi & 2 \\
\hline Akademik Çalışmaların Artması & 2 \\
\hline Arkeoloji Atölyesinin Olması & 2 \\
\hline Yöneticinin Liyakatli Olması & 1 \\
\hline TUBİTAK Baskısının Kalkması & 1 \\
\hline Okul Dışı Öğrenme Etkinlerinin Arttırılması & 1 \\
\hline Okuldaki Ders Yükünün Azalması & 1 \\
\hline Çocuk Parkının Olması & 1 \\
\hline Öğrenciye Somut Getirilerinin Olması & 1 \\
\hline Sergi Alanın Olması & 1 \\
\hline Tarih Bilincinin Olması & 1 \\
\hline Lise Öğrencilerinin Sayısının Artması & 1 \\
\hline Zümreden Yenilikçi Fikirler Oluşturulması & 1 \\
\hline
\end{tabular}

Tablo 10 incelendiğinde öğretmenlerin BİLSEM’lerde olmasını istediklerine yönelik görüşlerine ilişkin bulgulara bakıldığı zaman öğretmenlerin görüşlerinin dağınık olarak söylendiğini ifade etmek mümkündür. BİLSEM tarih öğretmenlerinin en fazla "okul müzesinin olması”, “tarih sınıfının olması”, " proje odaklı öğrencilerin olması" ve "öğrenci devamlılığının sağlanması" yönünde görüşler belirttiklerini söylemek mümkündür. Ayrıca öğretmenlerin BİLSEM’lerde zaman kavramının öğrenci ile öğretmen arasında sorun olarak ortadan kaldırılmasını ve nitelikli eğitim yapılmasını istedikleri görülmektedir. Bulgular genel olarak değerlendirildiğinde ise, tarih öğretmenlerinin üretkenliği ve verimliliği yüksek öğrenci potansiyelinin BİLSEM'de daha fazla olması, BİLSEM'lerde branş sınıflarının olarak, her branşa ait atölyelerin nitelikli oluşturulması, öğrencilerin örgün eğitimin yanı sıra BİLSEM eğitimlerinin de zaman engeli dışında sürekli olması ve akademik çalışmalara ağırlık verilerek BİLSEM'lerde liyakat şartına daha çok ağırlık verilmesi yönünde beklentilerinin olduğunu belirtmek mümkündür. Öğretmenlerin görüşlerinden bazıları şu şekildedir:

"Herkesin tarih bilincinde olduğu okul" (KÖ, 2).

"Diğer branşlar gibi eşit ilgi görmek beni mutlu eder." (EÖ, 6).

"Normal süreçte öğrencilerimi okul dışı öğrenme ortamlarına götürmek istiyorum ancak zaman ve şartlar uygun olmuyor bunlar çözülebilir ulaşım sorunu başta" (KÖ, 15).

"Tarih alanına özgü genel müdürlük düzeyinde tasarlanmış bir tarih atölyesi olması beni çok mutlu eder" (EÖ, 22).

"Sınıfımda proje yapan ne kadar çok öğrenci olursa o kadar mutlu olurum." (EÖ, 24).

\section{SONUÇ ve TARTIŞMA}

BİLSEM'lerde çalışan tarih öğretmenlerinin çalışma koşullarına yönelik görüşlerini almayı amaçlayan bu araştırmanın sonuçlarına göre: ilk olarak çalışma grubundaki tarih öğretmenlerinin, BİLSEM öğrencisinin; merak, ilgi, öğrenme, kavrama, algılama gibi becerilerinin yüksek olmasından memnuniyet duyduklarını ifade etmek mümkündür. Ayrıca programın; bölgenin, sosyal özellikleri, ekonomik yapısı ve öğrencilerin ilgi, ihtiyaç ve sosyal çevrenin değişen şartlarına göre düzenlenebilmesinin öğretmenlerin memnuniyet durumlarına olumlu yönde katkı sunduğu söylenebilir. Çalışma grubundaki öğretmenlerin genel olarak BİLSEM'lerin kurumsallaşamamasından kaynaklı problemler yaşasalar da BİLSEM'e karşı olumsuz bir tutum içinde olmadıkları görülmektedir. Semerci ve Kaya (2007)'nın çalışmaları da bu verileri destekler niteliktedir. Araştırma sonuçlarına göre ayrıca katılımcıların BİLSEM'lerde en önemli sorun olarak, idarecilerin BİLSEM'lere uygun atama biçimi ile atanmamasından ve öğrencilerin okul ve BİLSEM eğitimini beraber sürdürmelerinden kaynaklandığını ifade ettikleri görülmüştür. 
Çalışma sonucu bu açıdan Bozan ve Savi-Çakar (2020) ve Akhan ve Altaş (2020)'ın çalışma sonuçlarıyla benzerlik göstermektedir. Ayrıca katılımcıların çoğu, BíLSEM'lerin işleyişiyle ilgili olarak; öğrenci seçim şeklinin değiştirilmesi, fiziksel imkân ve teknolojik altyapının iyileştirilmesi, üniversitelerle bağlantının daha çok artması gerektiği görüşünü paylaşmışlardır. Tarih dersi özelinde ise katılımcıların çoğu tarih dersinin önemsenmeyen bir ders olduğu görüşünü paylaşmış ve bu duruma idarecilerin, ailelerin ve öğrencilerin tarih alanına bir bilim olarak bakmamalarının sebep olduğunu belirtmişlerdir. İdarecilerin, velilerin ve öğrencilerin sayısal derslere verdikleri önemi bu derse de vermeleri gerektiğini ifade etmişlerdir. Pek çok öğretmenin karşılaştı̆̆ı sorunlar arasında ise hizmet içi eğitimin yetersizliği ile ilgili yaşanan sorunlar, yönetmeliğin olmamasından kaynaklı sorunlar ve velilerin, öğrencilerin eğitimiyle ilgili beklentilerine yönelik yaşanan sorunlar yer almaktadır. Özkan (2009)'ın çalışmasında da BILSEM'lerde uygulanan programın MEB tarafından hazırlanıp üniversiteler ve TÜBİTAK gibi kurumlar tarafından zenginleştirilmesine ihtiyaç duyulduğu, BİLSEM'lerin yönetmelik yerine yönergeye dayalı yürütülmesinin sorun yarattığını, öğretmen ve yöneticilerin gelişimlerine katkı sağlayacak; üstün yeteneklilerin eğitimi ile ilgili hizmet içi eğitim seminerlerini yeterli bulmadıkları sonucuna ulaşmıştır. Altun ve Vural (2012')' in çalışmasında öğretmen kalitesinin artırılması için donanımlı okullara, maddi doygunluğun önemine ve genelde kişisel gelişim ve akademik alandaki gelişmelerle ilgili kurslar verilmesine vurgu yapmışlardır. Akhan ve Altaş (2020)'ın çalışmaları da benzer sonuçları içermesi açısından ulaştığımız sonuçları desteklemektedir. Ayrıca benzer olarak Kazu ve Şenol (2012)'un ve Sezginsoy (2007)'un araştırmasında da öğretmenlerin merkezlerdeki fiziksel donanım durumunun yeterli bulmadıkları sonucuna ulaşılmıştır. Diğer bir deyişle; merkez öğretmenleri merkezlerin bina donanım durumlarını, materyal, malzeme, oyun aracı, oyun alanı, bilgisayar, kütüphane kaynak durumlarını yeterli bulmadıkları sonucuna varılmıştır. Tantay (2010)'ın araştırmasının sonuçlarında da öğretmen görüşleri BİLSEM'lerde fiziki olarak birçok eksiklikler bulunduğu yönündedir. Su (2020)'nun BİLSEM'de çalışan matematik öğretmenlerinin matematik eğitiminde yaşadıkları sorunların incelenmesi çalışmasında fiziksel şartlar ve teknolojik alt yapı ve donanım eksiklerinin tesit edilmesi çalışmamızla benzerlik göstermektedir. Dolayısıyla bu sonuçların araştırmanın sonuçlarını desteklediği görülmektedir.

Araştırmanın sonuçlarını genel olarak değerlendirmek gerekirse, çalışma grubundaki öğretmenlerin çalışma koşulları konusunda yaşanan eksikleri olmasına rağmen kurumda olmaktan mutlu oldukları ve BíLSEM'de çalışmaya devam etme konusunda istekli oldukları ve beklentilerinin karşılanması yönünde atılacak adımların motivasyonlarına ve verimliliklerine katkı sağlayacağını söylemek mümkündür.

Araştırmadan elde edilen sonuçlar ışığında şu önerilerde bulunmak mümkündür:

- BİLSEM’lerin tam zamanlı olarak yapılandırılmasına yönelik olarak Millî Eğitim Bakanlığı tarafından çalışma başlatılabilir.

- BILLSEM idarecilerinin seçimi liyakat esaslı yapılabilir.

- Okul idarecilerinin alanlar ve öğretmenler arasında ayrım yapmalarının ve keyfi uygulamalarda bulunmalarının önüne geçmek için Millî Eğitim Bakanlığı okul idarecilerine yönelik olarak çalışma yapabilir.

- BİLSEM tarih öğretmenlerine yönelik hizmet içi eğitim programları düzenlenerek ihtiyaç duydukları konularda yetişmeleri ve kendilerini yenilemeleri sağlanabilir. 


\section{KAYNAKÇA}

Agaoğlu, O. (2011). Bilim ve sanat merkezlerinde görev yapan yönetici ve öğretmenlerin iş doyumu. (Yayımlanmamış Yüksek Lisans Tezi) Ankara Üniversitesi Eğitim Bilimleri Enstitüsü, Ankara.

Akhan, N. E. \& Altaş, S. (2020). Bilim ve sanat merkezlerindeki sosyal bilgiler öğretmenlerinin çalışma koşullarına yönelik görüşleri. A. Dinç (Moderatör), International Aegean Semposiums On Socıal Scıences \& Humanttıes içinde. Uluslararası Ege Sempozyumu, İzmir

Altun, T. \& Vural, S. (2012). Bilim ve sanat merkezinde (BİLSEM) görev yapan öğretmen ve yöneticilerin mesleki gelişim ve okul gelişimine yönelik görüşlerinin değerlendirilmesi. Elektronik Sosyal Bilimler Dergisi, 11(42), 152177.

Bozan, İ. \& Savi-Çakar, F. (2020). Bilim ve sanat merkezi öğretmenlerinin yaşadıkları sorunlar ve bu sorunlara ilişkin çözüm önerilerinin belirlenmesi. Turkish Studies Education, 15(3), 1607-1628.

Çal, Ü. T. (2018). Üstün yetenekli öğrencilerin eğitiminde sosyal bilgiler eğitiminin yeri ve önemi (Yayımlanmamış Yüksek Lisans Tezi) Akdeniz Üniversitesi Eğitim Bilimleri Enstitüsü, Antalya.

Dönmez, N. B. (2019). Kişisel web sayfası. http://www.necatebaykoc.com.tr/bilsem/ adresinde 21.09.2020 tarihinde incelenmiştir.

Güven, D. (2010). Profesyonel bir meslek olarak Türkiye'de öğretmenlik. Boğaziçi Üniversitesi Ĕ̆itim Dergisi, 27(2), 13-21.

Karasar, N. (2012). Bilimsel araştırma yöntemleri (24. baskı). Ankara: Nobel.

Karataş, K. (2020). Öğretmenlik mesleğine kuramsal bir bakış. Electronic Journal of Education Sciences, 9(17), 39-56.

Kazu, İ. Y. \& Şenol, C. (2012). Üstün yetenekliler eğitim programlarına ilişkin öğretmen görüşleri (BILLSEM örneği). Uluslararası Eğitim Araştırmaları Dergisi, 3(2), 13-35.

MEB (1991). Özel eğitimle ilgili mevzuat. Ankara: Milli Eğitim Basımevi.

MEB (2019). Bilsem yönergesi. Tebliğler Dergisi, Ankara. 390-427.

Mertol, H. (2014). Türkiye ve ABD'de üstün zekâlı çocuklara sosyal bilgiler dersi veren öğretmenlerin görüş ve uygulamalar (Yayımlanmamış Doktora Tezi). Atatürk Üniversitesi Eğitim Bilimleri, Erzurum.

Miles, M. B. \& Huberman, A. M. (1994). Qualitative data analysis: An expanded sourcebook. (2nd ed). Thousand Oaks, CA: Sage.

Özkan, D. (2009). Yönetici, öğretmen, veli ve öğrenci görüşlerine göre bilim ve sanat merkezlerinin örgütsel etkinliği. (Yayınlanmamış Yüksek Lisans Tezi). Ankara Üniversitesi Eğitim Bilimleri Enstitüsü, Ankara, Türkiye.

Safran, M. (2009). Türkiye'de tarih öğretimi ve meseleleri. M. Demirel \& İ. Turan (Eds.), Tarih Öğretim Yöntemleri içinde (s. 7-25). Ankara: Nobel Yayınları.

Semerci, N. \& Kaya, E. (2007). Bilim ve Sanat Merkezlerinde (BİLSEM) görev yapan öğretmenlerin BİLSEM'e yönelik görüşleri. Sosyal Bilimler Araştırmaları Dergisi, 2(2), 230-242.

Sezginsoy, B. (2007). Bilim-sanat merkezi uygulamasının değerlendirilmesi. (Yayınlanmamış Yüksek Lisans Tezi). Balıkesir Üniversitesi Sosyal Bilimler Enstitüsü Eğitim Bilimleri Anabilim Dalı, Balıkesir: Türkiye

$\mathrm{Su}$, G. (2020). BİLSEM'de çalışan matematik öğretmenlerinin matematik eğitiminde yaşadıkları sorunların incelenmesi (Yayımlanmamış Yüksek Lisans Tezi) Mersin Üniversitesi Eğitim Bilimleri Enstitüsü, Mersin.

Tantay, Ş. (2010). Özel veya üstün yetenekli çocuklara eğitim veren okul ve merkezlerin incelenmesi. (Yayınlanmamış Yüksek Lisans Tezi). Maltepe Üniversitesi Sosyal Bilimler Enstitüsü Eğitim Bilimleri Anabilim Dalı, İstanbul, Türkiye.

Terzi, S. (2017). Öğretmenlerin iş doyumları ile mutluluk düzeyleri arasındaki ilişkinin incelenmesi. 21. Yüzyılda Eğitim ve Toplum Dergisi, 6(17), 475-478.

Yıldırım. A. \& Şimşek. H. (2013). Sosyal bilimlerde nitel araştırma yöntemleri (9. Baskı). Ankara: Seçkin Yayınları. 
Yörük, S., Çankaya, İ., Büyükakın, İ.E., \& Kızılkaya, H. (2013). Bilim sanat merkezlerinde çalışan öğretmenlerin iş doyumlarının bazı örgütsel faktörlere göre incelenmesi: Ankara ve Afyonkarahisar örneği. Uşak Üniversitesi Sosyal Bilimler Dergisi, 6(ÖYGE Özel Sayıs1), 312-333. 


\section{Extended Abstract}

\section{Introduction}

History teachers who prepare and implement the history program in Science and Art Centers (BILSEM) may face many problems. Knowing what these teachers' opinions about BILSEMs will help explain the organizational structure and functioning of BILSEM and the problems encountered during this process. In this direction, the purpose of the present research is to reveal the opinions of history teachers working in BILSEMs concerning their working conditions.

\section{Method}

The descriptive model was adopted in this research, in which qualitative research method was used. Descriptive studies try to define the events, individuals, or objects, which are the subjects of the researches, in their own conditions and as it is. They do not attempt to change or influence them in any way. The present research was conducted with 27 history teachers determined in accordance with the convenience sampling method, which is one of the purposive sampling methods, serving in Science and Art Centers in various provinces of Turkey in the 20202021 academic year. The research data were collected with the help of a semi-structured interview form prepared by the researchers. The open-ended questions prepared were transferred to the question form via "Google Form" and then the history teachers were contacted via WhatsApp service on the phone and requested to answer the questions. Generally, the questions aimed to determine the "History teachers" opinions about the organizational structure and functioning of BILSEM, the situations that caused positive or negative opinions in their attitudes towards the administrators and students, and whether their expectations from BILSEM about the field of history were met. The data obtained from the research were analyzed with the descriptive analysis technique. In the descriptive analysis, the data obtained are summarized and interpreted according to predetermined themes.

\section{Findings}

When the answers given to the interview form used in the study are examined, the following conclusion can be drawn: the teachers 'opinions about the positive sides of BILSEMs are that they offer a comfortable working environment that increases productivity and efficiency and that the students have a high level of knowledge. The problems related to BILSEMs are that they lack standard administrative management, working spaces are inadequate, teachers' working hours are after their formal education working hours, students' productivity decreases due to their heavy workload in formal education and BILSEM. As for the opinions of the history teachers concerning the functioning of the BILSEM, they think that problems arising from the students' receiving their current formal education first and then allocating the remaining hours to BILSEM and the teachers' working at BILSEM at rather late hours of the day should be solved and changes should be initiated to improve the physical facilities. Moreover, BILSEM history teachers feel free and happy within the institution as they can create an opportunity to increase the productivity and creativity of students on the basis of projects, but feel uncertain and lonely due to a lack of coordination between the administration and the teachers within the institution. Regarding the teachers' opinions about the attitudes of the administrators in BILSEM towards history lesson, it can be said that their attitudes were mostly positive due to the scientific significance and necessity of the history lesson, but a small number of teachers were of the opinion that the administrators had a negative attitude due to their low sense of responsibility. BILSEM history teachers expect their administrators to attach the necessary importance to the history course, to provide material and moral support for history workshops and history classes, and to lead projects that will develop historical empathy in order to enable students to judge between the past and the present. A majority of the history teachers think that the history lesson attracts the attention of the students because the history course demands active participation of the students and the subjects of history are analyzed within the framework of the cause-effect relationship, but some of the teachers are of the opinion that the history lesson does not attract the attention of the students because it is a verbal course and that the parents' perception of success is based on quantitative courses which puts pressure on students. On the other hand, the history teachers expect their students to gain the historical 
reasoning ability, to increase their national consciousness and feeling by keeping their sense of curiosity at the highest level, and to accumulate a vast amount of knowledge to serve as a bridge between the past and the future. The history teachers believe that BILSEMs host students with higher productivity and efficiency rates but think that qualified workshops should be created for each branch at BILSEMs, and students should have BILSEM classes without time constraints in addition to their formal education. Moreover, emphasis should be laid on academic studies in BILSEMs, and the merits of the teachers should be prioritized in their selection.

\section{Result and Discussion}

According to the results of this study, which aimed to determine the opinions of history teachers working in BILSEM institutions about their working conditions, firstly, it can be stated that the history teachers in the sample are pleased that the BILSEM students possess remarkable skills in areas such as curiosity, interest, learning, comprehension and perception. In addition, it can be said that the ability of the program to be adjusted to the economic and social characteristics of the region and to the students' interests and needs, as well as the changing conditions of the social environment positively contribute to the teachers' satisfaction. It is observed that although the teachers in the sample generally experience problems due to the inability of BILSEMs to institutionalize, they do not have a negative attitude towards BILSEM. A study by Semerci and Kaya (2007) also supports these data. According to the results of the present research, the participants thought that the most important problem in BILSEMs was that the administrators were not appointed to the BILSEMs through an appropriate appointment procedure and that the students continued their school and BILSEM education together. In this respect, the result of the study is similar to the results of studies by Bozan and Savi-Çakar (2020) and Akhan and Altaş (2020). In addition, regarding the functioning of BILSEMs, most of the participants shared the view that the method of student selection should be changed, physical facilities and technological infrastructure should be improved, and cooperation with universities should be further increased. In terms of history lesson, most of the participants shared the view that history lesson is an underestimated lesson and stated that it was the reason why administrators, families and students did not consider history as a science. They stated that administrators, parents and students should attach the same importance to this course as they attach to quantitative lessons. A study by Akhan and Altaş (2020) reveals similar findings and therefore support the results we have reached.

To evaluate the results of the research in general, it can be said that the teachers in the sample are delighted to be at BILSEM despite the deficiencies in the working conditions and they are willing to continue to work in the institution and that steps that will be taken to meet their expectations will contribute to their motivation and efficiency.

\section{Araştırmanın Etik İzinleri}

Yapılan bu çalışmada “Yükseköğretim Kurumları Bilimsel Araştırma ve Yayın Etiği Yönergesi” kapsamında uyulması belirtilen tüm kurallara uyulmuştur. Yönergenin ikinci bölümü olan "Bilimsel Araştırma ve Yayın Etiğine Aykırı Eylemler" başlığı altında belirtilen eylemlerden hiçbiri gerçekleştirilmemiştir.

Etik değerlendirmeyi yapan kurul adı: Akdeniz Üniversitesi Sosyal ve Beşeri Bilimler Bilimsel Araştırma ve Yayın Etiği Kurulu

Etik değerlendirme kararının tarihi: 18.09.2020

Evrak Tarih ve Sayıs1: 23/09/2020-100607 